\title{
Spatial and temporal variability of ozone deposition
}

\author{
Cs. Czender ${ }^{1,2}$, E. Komjáthy ${ }^{2}$, R. Mészáros ${ }^{2}$, and I. Lagzi ${ }^{2}$ \\ ${ }^{1}$ Hungarian Defence Forces, Geoinformation Service, Budapest, Hungary \\ ${ }^{2}$ Department of Meteorology, Eötvös Loránd University, Budapest, Hungary
}

Received: 31 December 2008 - Revised: 16 March 2009 - Accepted: 18 March 2009 - Published: 1 April 2009

\begin{abstract}
Soil moisture and ozone deposition velocity under continental climate conditions were estimated using a newly developed algorithm. The relationship between soil moisture and deposition velocity was investigated and analysed. These results emphasize the importance of a sophisticated parameterization of soil moisture in surface-atmosphere interaction processes.
\end{abstract}

\section{Introduction}

In the last few years, many researches have pointed out the differences between concentration- and flux-based indices that can be applied for the characterization of effective ozone load (Musselman et al., 2006; Paoletti and Manning, 2007). New indices have been introduced which can more effectively describe the actual destructive effects of ozone. These indices can be estimated using deposition models. In such models, the ozone flux is controlled by ozone concentration and deposition velocity. For the purpose of calculating the deposition velocity, a high resolution deposition model was developed and tested over a continental region (Lagzi et al., 2004; 2006; Mészáros et al., 2006, 2009a). Previous investigations and sensitivity analysis (Mészáros et al., 2009a, b) have shown that in the summer period, the soil moisture could be a crucial stress factor in the deposition processes. Therefore a newly developed, more detailed water-balance module was adapted for use in our deposition model.

The main goal of this study is to present the temporal and spatial variability of ozone deposition velocity under continental climate conditions and to reveal the relationship of the deposition velocity with soil moisture.

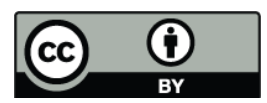

Correspondence to: R. Mészáros (mrobi@nimbus.elte.hu)

\section{Deposition model}

Ozone deposition velocity was estimated using the resistance method. In this model, the deposition velocity is defined as the inverse of the sum of the atmospheric and surface resistances:

$v_{d}=\left(R_{a}+R_{b}+R_{c}\right)^{-1}$,

where $R_{a}, R_{b}$, and $R_{c}$ are the aerodynamic resistance, the quasi-laminar boundary layer resistance, and the canopy resistance, respectively. The canopy resistance is parameterized using stomatal, cuticular and surface resistance terms and depends on both meteorological and soil data and physiological plant characteristics. The ozone flux through the stomata can be depressed or sometimes fully blocked by high or low temperature, high vapour pressure deficit, and low soil moisture. Details of the deposition model are described in Mészáros et al. (2009a).

In this study, the daytime (12:00 UTC) deposition velocity was calculated for three summer periods (from 1 April to 30 September 1998 and 2007, and from 1 April to $31 \mathrm{Au}-$ gust 1999).

The input meteorological datasets in $0.1 \times 0.15$ degrees spatial resolution were taken from the ALADIN meso-scale limited area numerical weather prediction model. These data were interpolated to a finer spatial resolution grid $(0.025 \times 0.0375$ degrees, about $2.5 \times 2.5 \mathrm{~km})$. According to the Land Use Categories (LUC) used in ALADIN model, eight different vegetation types (grass, agricultural land, orchard, mixed agricultural land and forest, coniferous forest, deciduous forest, mixed forest and moorland) in addition to water and built-up areas were distinguished. Calculations were performed for seven soil types (sand, sandy loam, loam, clay loam, clay, peat and coarse frame). Root-zone soil moisture

Published by Copernicus Publications. 
was estimated by a prognostic bucket model with a daily time step.

\section{The water-balance module}

The soil moisture is estimated in a bucket which depth is taken to be the root zone depth $\left(z_{r}\right)$, the lateral movement and motion of the water into and from the lower layers are neglected. A root zone depth of $1 \mathrm{~m}$ was chosen for all soil types except for peat and coarse frame which were set at $0.2 \mathrm{~m}$ in the model. The soil moisture $(\theta)$ of the following time step ( $i+1$ th day) is calculated by the actual $(i$-th) daily values (Mintz and Walker, 1993):

$\theta_{i+1}=\theta_{i}+\left(P_{i}-I_{i}\right)-E T_{i}$

where $P, I$ and $E T$ are the precipitation, the interception and the evapotranspiration, respectively.

The soil moisture is determined by the volumetric waterholding properties of the soil.

In the water-balance module, the evapotranspiration $(E T)$ is calculated as the sum of evaporation of the bare soil $\left(E_{d i r}\right)$ and the transpiration of the vegetation $\left(E_{t}\right)$ :

$E T=E_{d i r}+E_{t}$,

$E_{d i r}=E_{p}(1-\mathrm{veg}) \beta_{1}, \quad$ and $\quad E_{t}=E_{p} v e g \beta_{2}$

where $E_{p}$ is the potential evapotranspiration, which is calculated by Penman-based approach, veg is the percentage distribution of vegetation, which ranges between 0 and $1, \beta_{1}$ and $\beta_{2}$ are functions of the soil moisture and canopy resistance, respectively. $E_{p}$ and $\beta$ functions are calculated after Chen and Dudhia (2001), the soil parameters using for the estimation of $\beta_{1}$, as wilting point, and field capacity soil moisture content are parameterized after Ács (2003). The ratio of vegetation coverage (veg) for every cell was determined based on dataset of ALADIN model. For every vegetation type in a given cell the same vegetation fraction value was assumed.

The precipitation, which reaches the soil of a vegetated surface, is reduced by the amount of water intercepted by the canopy $(I)$. The amount of the intercepted water on wet days (if there is precipitation) is estimated by the following relation:

$I=S_{m} \mathrm{LAI}$

where LAI is the leaf area index $\left[\mathrm{m}^{2} \mathrm{~m}^{-2}\right], S_{m}$ is the maximum water storage capacity per unit leaf area index $(0.2 \mathrm{~mm}$ in the model). The upper limit of the amount of the intercepted water is the daily precipitation. Because the water balance model is in a daily time step, it is assumed that the intercepted water is totally evaporated during the day. Therefore, the evaporation of the wet canopy is equal to the daily interception.

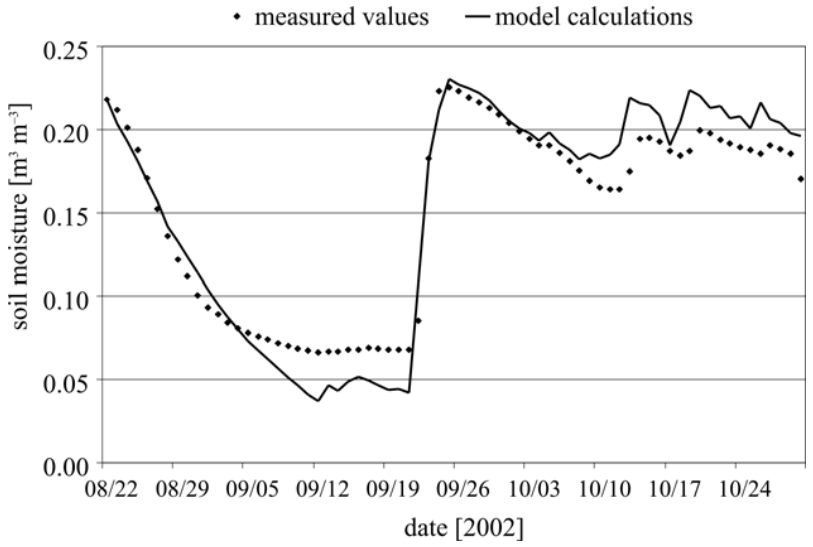

Figure 1. Measured and modelled soil moisture in the upper soil layer in Bugacpuszta.

\section{Results}

\subsection{Comparison with measurements}

The calculations of the water-balance module were verified with measurements in Bugacpuszta, Hungary $\left(\varphi=46^{\circ} 40^{\prime} \mathrm{N}\right.$, $\lambda=19^{\circ} 33^{\prime} \mathrm{E}, h=110 \mathrm{~m}$ ). Here the soil type is sand and the land use category is grass. Measurements were carried out by a Campbell CS615 TDR sensor in the upper layer of soil. Measured data were available from 22 August to 30 October 2002. Daily average values were calculated from measurements at 12:00 and 00:00 UTC. Root-zone depth in the model was chosen to $0.25 \mathrm{~m}$.

Figure 1 represents the calculated and the measured soil moisture data from the above mentioned period. The model underestimated the soil moisture in the dryer period (September) and slightly overestimated it in wet period (October). The reason of these discrepancies may be due to neglecting of horizontal and vertical water movements outside of the thin bucket. However there is a good correlation between measured and modelled values and the dynamics of soil moisture (quick growth after precipitation, and the degree of soil desiccation) can be traced with the model.

\subsection{Model results}

Figure 2 shows the spatial distribution of monthly averages of soil moisture and 12:00 UTC ozone deposition velocity values in July 1998, 1999 and 2007. Soil moisture patterns following the spatial distribution of soil types, and the different weather situations can cause differences in soil moisture among each year for the same period. In 1998 and 2007, the summer was very hot, although high monthly precipitation was observed in the summer of 1998 and 1999, while 2007 was a dryer year. Therefore due to the higher evapotranspiration and lower amount of precipitation, the soil moisture in July was the lowest in 2007. The soil water deficiency can 


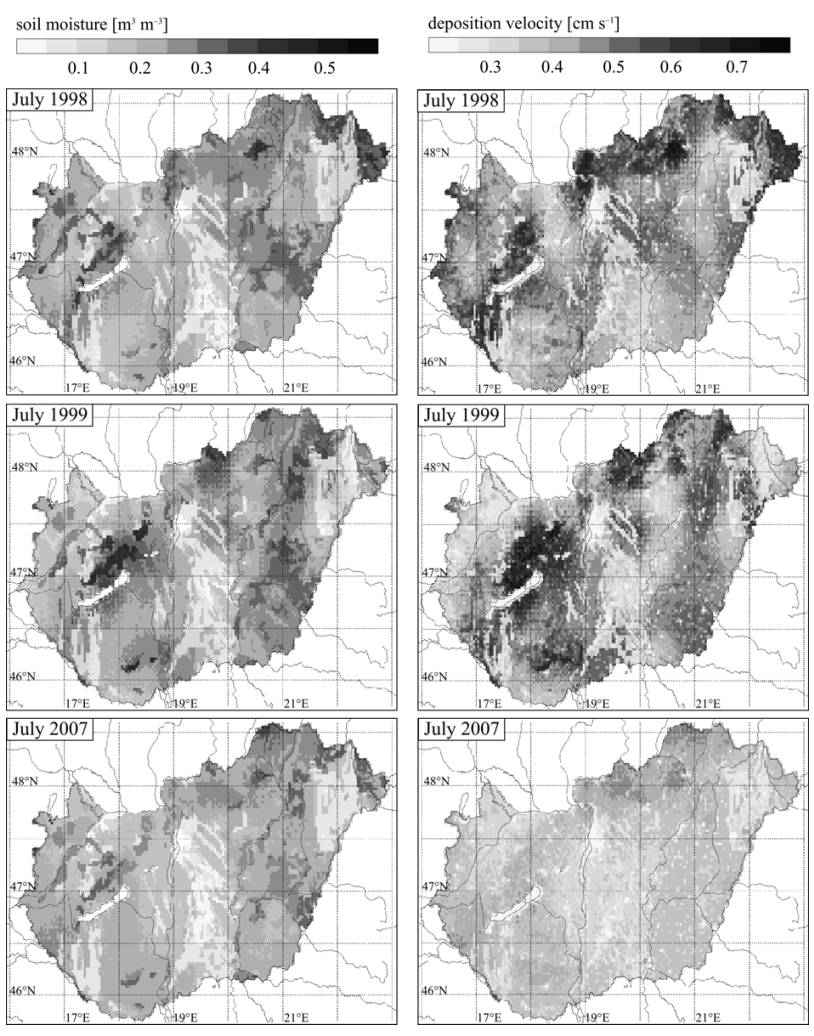

Figure 2. Soil moisture and ozone deposition velocity fields in July of 1998, 1999 and 2007.
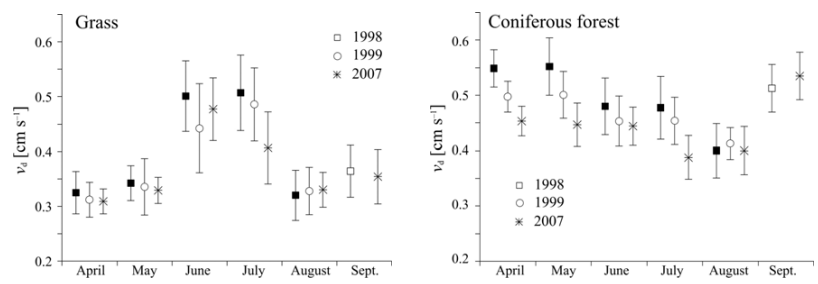

Figure 3. Deposition velocities (average and standard deviation) over grass and coniferous forest.

strongly reduce the stomatal conductance and so the ozone deposition through it. Therefore, there is a good correlation between the spatial and temporal distribution of soil wetness and deposition velocity fields.

Temporal variability of 12:00 UTC ozone deposition velocity during three summer periods are presented in Fig. 3 for grass and for coniferous forest. According to different plant physiology and characteristics, there are significant differences among deposition velocities in each month even as over each surface type. Due to the plant growth (increasing leaf area index), and the optimal environmental conditions for vegetation (higher temperature together with sufficient soil water content), generally higher values occur in June and July for grass. However, for coniferous forest, higher depo- sition velocity values were obtained in spring. In this case there are no significant changes in leaf area indices between each period, at the same time the lower temperature in spring is more favourable for the stomatal uptake of this type of vegetation. Decreasing soil water content (due to the warmer period of the year without precipitation) in August (or in July in 2007) decreased the deposition velocities in all cases. In contrast of this, in September, the values were raised because the soil water content was increased again.

These results emphasize the important effects of soil moisture in the surface-atmosphere interactions, especially in deposition processes.

Acknowledgements. The authors acknowledge the support of the Hungarian Research Fund (OTKA K68253). Ferenc Ács (Eötvös Loránd University) is acknowledged for helpful discussions.

Edited by: M. Piringer

Reviewed by: two anonymous referees

\section{References}

Ács, F.: On the relationship between the spatial variability of soil properties and transpiration, Idöjárás, 107, 257-272, 2003.

Chen, F. and Dudhia, J.: Coupling an Advanced Land SurfaceHydrology Model with the Penn State-NCAR MM5 Modeling System. Part I: Model Implementation and Sensitivity, Mon. Weather Rev., 129, 569-585, 2001.

Lagzi, I., Mészáros, R., Horváth, L., Tomlin, A., Weidinger, T., Turányi, T., Ács, F., and Haszpra, L.: Modelling ozone fluxes over Hungary, Atmos. Environ., 38, 6211-6222, 2004.

Lagzi, I., Mészáros, R., Ács, F., Tomlin, A. S., Haszpra, L., and Turányi, T.: Description and evaluation of a coupled Eulerian transport-exchange model. Part I: Model development, Idöjárás, 110, 349-363, 2006.

Mészáros, R., Lagzi, I., Juhász, Á., Szinyei, D., Vincze, Cs., Horányi, A., Kullmann, L., and Tomlin, A. S.: Description and evaluation of a coupled Eulerian transport-exchange model. Part II: Sensitivity analysis and application, Idöjárás, 110, 365-377, 2006.

Mészáros, R., Zsély, I. Gy., Szinyei, D., Vincze, Cs., and Lagzi, I.: Sensitivity analysis of an ozone deposition model, Atmos. Environ., 43, 663-672, 2009a.

Mészáros, R., Szinyei, D., Vincze, Cs., Lagzi, I., Turányi, T., Haszpra, L., and Tomlin, A. S.: Effects of the soil wetness state on the stomatal ozone fluxes over Hungary, Int. J. Environ Pollut., 36, No. 1/2/3, 180-194, 2009b.

Mintz, Y. and Walker, G. K.: Global fields of soil moisture and land surface evapotranspiration derived from observed precipitation and surface air temperature, J. Appl. Meteorol., 32, 1305-1334, 1993.

Musselman, R. C., Lefohn, A. S., Massman, W. J., and Heath, R. L.: A critical review and analysis of the use of exposure- and flux-based ozone indices for predicting vegetation effects, Atmos. Environ., 40, 1869-1888, 2006.

Paoletti, E. and Manning, W. J.: Toward a biologically significant and usable standard for ozone that will also protect plants, Environ. Pollut., 150, 85-95, 2007. 